\title{
INNOVATION CAPABILITIES IN EU COUNTRIES: HAVE CENTRAL AND EASTERN EUROPEAN COUNTRIES BEEN CATCHING UP?
}

\author{
Monika KONDRATIUK-NIERODZIŃSKA \\ Department of Economic Systems, Economics and Management Faculty, University of \\ Bialystok, ul. Warszawska 63, 15-062 Białystok, Poland \\ E-mails:mkn@uwb.edu.pl; monika.mkn@gmail.com
}

Received 23 March 2015; accepted 26 October 2015

\begin{abstract}
The paper answers two questions: which innovation capabilities most strongly differentiate CEECs and highly developed European economies and to what extent CEECs' performance within each of the innovation capabilities has changed over a decade. The research method is based on construction of composite indicators describing national performance within five innovation capabilities in two periods: 1998-2000 and 2010-2012 as well as regression analysis in order to test the accuracy of the main findings. The study has allowed to arrive at a conclusion that CEECs have been able to catch up to highly developed European economies with respect to absorptive capacity related to the existence and use of technological infrastructure as well as participation in inward technology transfer in the form of FDI and capital goods imports. There is, however, a lingering performance gap in new knowledge and innovation creation capabilities and R\&D effort. Continuation of this trend and lack of considerable improvement also in terms of absorptive capacity related to the quality of human resources might result in CEECs' permanent inability to catch up to their highly developed European counterparts.
\end{abstract}

Keywords: Central and Eastern Europe, innovation capabilities, innovation systems, economic development, knowledge creation, absorptive capacity.

JEL Classification: O30, O39, P52.

\section{Introduction}

Since the early 1990s when Central and East European countries (CEEC) stepped on a path of transition towards internationally integrated market economies the restructuring of their domestic economies began. The process was aimed at catching up with highly developed countries in terms of economic growth and per capita income levels. It involved considerable changes in their economic structure as well as transformation of their political and social systems. However, growth in CEECs has been driven mainly by changes in production, which suggests problems with its sustainability (Kravtsova, Radosevic 2012: 110, 122). Highly developed OECD countries rely on their innovation capabilities as the main drivers of economic growth, which is something most of the CEECs countries find hard to duplicate/follow. 
The early contribution to the understanding that technological development may be one of the most important determinants of economic growth and development is attributed to historically oriented economists (Castellacci 2003; Fagerberg, Srholec 2008). They have stressed the fact that economic growth is a process of long-term transformation shaped by the complex interactions between technology, economy, institutions and social factors (see: Fagerberg 1994; Castellacci 2003; Fagerberg, Godinho 2005 for overviews). Since then, and most of all since 1980s, a lot of studies on the nature and measurement of technological capabilities and cross-country differences in levels of development and growth performance inspired by this perspective emerged. Part of the work in this area focused mostly on comparing the impact, which technological and other factors have on economic performance of nation states, thus on searching for and in most cases finding a proof of a positive relationship between technological advancement and economic development (Freeman et al. 1982; Fagerberg 1987, 1988a, 1994, 2000; Dosi et al. 1990; Verspagen 1991; Freeman 2002; Fagerberg, Verspagen 2003; Goo, Park 2007; Fagerberg et al. 2007; Fagerberg, Srholec 2008; Hasan, Tucci 2010). The line of this research included looking for reasons behind the existence of technological differences (technology gaps) and falling behind rather that catching up in case of certain groups of countries (Fagerberg 1987, 1988a, 1988b; Verspagen 1991; Fagerberg, Verspagen 1996, 2002, 2003; Fagerberg et al. 2007; Fagerberg, Srholec 2008; Filippetti, Payrache 2011; Fagerberg, Srholec 2013), as well as investigating factors influencing countries' potential for technology/innovation adoption and development (Furman et al. 2002; Furman, Hayes 2004; Faber, Hesen 2004; Cerulli 2014). Some authors, on the other hand, concentrated their efforts on measuring performance of national innovation systems and constructing composite indicators of technological/innovation capabilities that would allow to classify different countries according to their technological advancement, corresponding in fact to the level of their economic development (see Khayyat, Lee 2015 for overview).

Past research implies that differences in the level of economic development may be explained by variations in country performance within different innovation capabilities. However, attention has rarely been paid to how Central and Eastern European countries perform in terms of innovation capabilities since international view or performance of emerging economies and/or least developed countries of the world has been the main focus. Main interest of this study has been therefore shifted towards finding out which innovation capabilities most strongly differentiate CEECs and highly developed EU economies and answering a question to what extent CEECs have been able to catch up in terms of different innovation capabilities in the course of over a decade (1998-2012). The paper is structured as follows: Section 1 contains an overview of literature on technological/innovation capabilities as drivers of economic development and aims at the identification of the main innovation capabilities. In Section 2 a description of the accepted scheme of analysis is presented, including measures of each of the indentified innovation capabilities as well as adopted methodology for statistical data analysis. Section 3 contains a description of results and is followed by Conclusions. 


\section{Technological/innovation capabilities as drivers of economic development: overview of recent studies}

Technological capability of a country may be defined as "the ability to make effective use of technological knowledge in efforts to assimilate, use, adapt and change existing technologies" (Kim 1997: 4; cited in Fagerberg, Srholec 2008: 1419). This concept draws from the idea of Cohen's and Levinthal's "absorptive capacity" of firms (1990: 128) and includes not only organized R\&D, but also other capabilities needed for the commercial exploitation of technology. In this sense it also relates to a systemic view of innovation, where a wide range of factors influencing innovation generation and diffusion processes are taken into account. National innovative capacity, a term used by Furman, Porter and Stern, has the same connotations and is defined as "the ability of a country - as both a political and economic entity - to produce and commercialize a flow of new-to-the world technologies over the long term" (Furman et al. 2002: 900). Therefore the term "technological capability" may be used interchangeably with the term "innovation capability" or "innovation capacity".

The literature on the subject offers different views on the composition of technological/ innovation capabilities of nations. The above mentioned concept of "absorptive capacity" seems to have a lot of bearing on the understanding of factors influencing technological output and economic development of nations. According to Abramovitz (1986, 1994), absorptive capacity may refer to "technological congruence", meaning "resource availabilities, factor supplies, technological capabilities, market scales and consumer demands", as well as broadly defined "social capability" (Abramovitz 1994: 24). The subject was taken up by Verspagen (1991) who spoke about "intrinsic" learning capability, which he defined as depending on such variables as the education of the labour force and the quality of the infrastructure. Keller (1996) also adopted a view that the absorptive capacity of an economy has considerable influence over its performance but his definition of the term was narrower as he defined it as specific skills and knowledge accumulated in domestic human capital. The concept is also present in Fagerberg's and Verspagen's work $(2002,2003)$ who distinguished between three sets of factors, which in their opinion help to explain economic growth: (1) innovation understood as creation of new knowledge in the country, (2) diffusion, i.e. potential for exploiting knowledge developed elsewhere and (3) absorptive capacity understood as complementary factors that contribute to the exploitation of diffusion potential.

The importance of human capital, among other factors influencing creation and diffusion of new technologies, is also emphasised by other authors. Benhabib and Spiegel (1994), Papageorgiou (2002) and Stokke (2008) focused on human capital and learning capability as the most important factors of economic development, responsible for a country's ability to imitate and absorb foreign advanced technologies. Lall (1992) also mentioned human capital as one of the aspects of national technological capabilities. He distinguished three such aspects: (1) physical investment, (2) human capital and (3) technological effort (domestic and imported). The author emphasised that quantity of physical and human resources is even less important than their quality. National technological effort, according to the author, is to be associated with a broad spectrum of 
production, design and research work within firms, backed up by a technological infrastructure that provides information, standards, basic scientific knowledge and various facilities too large to be owned by private firms, but is also the result of the extent and nature of a country's reliance on foreign technology. Archibugi and Coco (2004), who proposed a new measure of technological capabilities of countries, also considered three dimensions of technological capabilities, among which they included characteristics of nation's human resources: (1) creation of technology, (2) technological infrastructures and (3) development of human skills.

Fagerberg and Srholec (2008), continuing research on the subject of specific national capabilities as factors influencing economic development, took a broader view and identified four types of capabilities/factors: (1) the development of the innovation system, (2) the quality of governance, (3) the character of the political system and (4) the degree of openness of the economy. In this case innovation capabilities of countries have been "summarised" by the term "development of the innovation system", which was measured using a relatively broad spectrum of indicators associated with different aspects of both technological and social capabilities of nation states. In their 2013 paper (Fagerberg, Srholec 2013) they used indicators related to innovation activities to describe broadly defined "social capabilities" of countries, since they found through factor analysis that there exists a strong interdependence between technological, social and cultural factors in the process of development.

Broad perspective on national innovation capabilities was shared by Furman et al. (2002) and Furman and Hayes (2004), who introduced a concept they termed a "national innovation capacity" (Furman et al. 2002) and described it as a result of three building blocks: (1) presence of a strong common innovation infrastructure (country's overall science and technology policy environment, support mechanisms of basic research and higher education and the cumulative "stock" of technological knowledge upon which new ideas are developed and commercialised), (2) specific innovation environments present in a country's industrial clusters (microeconomic environment in which firms compete), (3) strength of the linkages between the common innovation infrastructure and specific clusters, depending on mechanisms or institutions. Similarly, Faber and Hesen (2004) who also approached the subject of innovation capabilities from a perspective of factors influencing production of innovative output of an economy, argued that the concept of National Innovation Systems comprises two broad categories of variables: (1) related to innovation processes within and among firms, and (2) related to the innovation infrastructure surrounding and enabling innovations by firms, comprising economic, institutional and contextual conditions.

Castellacci and Natera (2013) also adopted a broad view on innovation capabilities. They discerned between two main factors influencing a country's level of economic development: (1) innovative capability, and (2) absorptive capacity. Innovative capability was described as: (a) innovative input representing total efforts and investments carried out by each country for R\&D and innovative activities, (b) scientific output denoting results of research and innovation activities carried out by the public S\&T system and (c) technological output defined as total output of technological and innovative activities 
carried out by private firms. Absorptive capacity, on the other hand, was considered to be determined by (a) international trade representing the openness of the national system and in turn influencing a country's capability to imitate foreign advanced knowledge, (b) human capital and its characteristics, (c) level and quality of infrastructures increasing a country's capability to absorb, adopt and implement foreign advanced technologies, (d) quality of institutions and governance system and (e) level of social cohesion and economic inequality influencing the pace of diffusion and adoption of advanced knowledge within the country.

Archibugi and Coco (2005) and Archibugi et al. (2009) point out that different views on technological/innovation capabilities of nations agree on the fact that they are composed of heterogeneous elements, which can be summarised in three contrasts: (a) embodied (i.e. capital good, infrastructure etc.)/disembodied (human skills and technological expertise), (b) codified (blueprints, patents etc.)/tacit (learning processes), and (c) generation (creation of new knowledge)/diffusion (assimilation of new knowledge generated elsewhere).

The above review of past research on the subject has determined the structure of innovation capabilities used for analysis in this study. Three types of innovation capabilities are taken into account: (1) new knowledge creation, (2) participation in technology transfer and diffusion and (3) absorptive capacity, dependant on three factors: (a) country's research and development effort in terms of human resources and expenditures, (b) quality of human capital and (c) the existence and use of technological infrastructures.

\section{Innovation capabilities in European countries - a scheme of analysis}

Figure 1 shows standard deviation of GDP per capita for three groups of European countries $^{1}$. Standard deviation is here an indicator of the disparity of income levels between those countries. Over the whole 1998-2012 period a steady rise of this indicator may be observed, which means that per capita income differentials have been growing instead of diminishing over time, although their growth has been slowed down by 2009 economic crisis. The average Real GDP per capita for a group of ten CEECs has risen during that period from 5310.00 EUR to 8600.00 EUR, but at the same time the gap between a group of nine Western and Northern European countries, used in this study for comparisons $^{2}$, has also risen from a little below 22000.00 EUR to almost 24000.00 EUR.

The basic assumption in this study, based on past empirical research on the relationship between technological/innovation capabilities and economic development, is that differences in the level of GDP per capita between European countries may be explained by still lingering differences in their innovation capabilities. Therefore this paper aims at answering two questions: which of the innovation capabilities defined in the previous section most strongly differentiate CEECs and highly developed European economies

\footnotetext{
${ }^{1}$ Two larger groups represent all European countries for which data on GDP per capita has been available and a group of 23 countries represents the sample used for the research presented in this paper.

${ }^{2}$ For information on which countries belong to which group see Table A1 in the Appendix.
} 


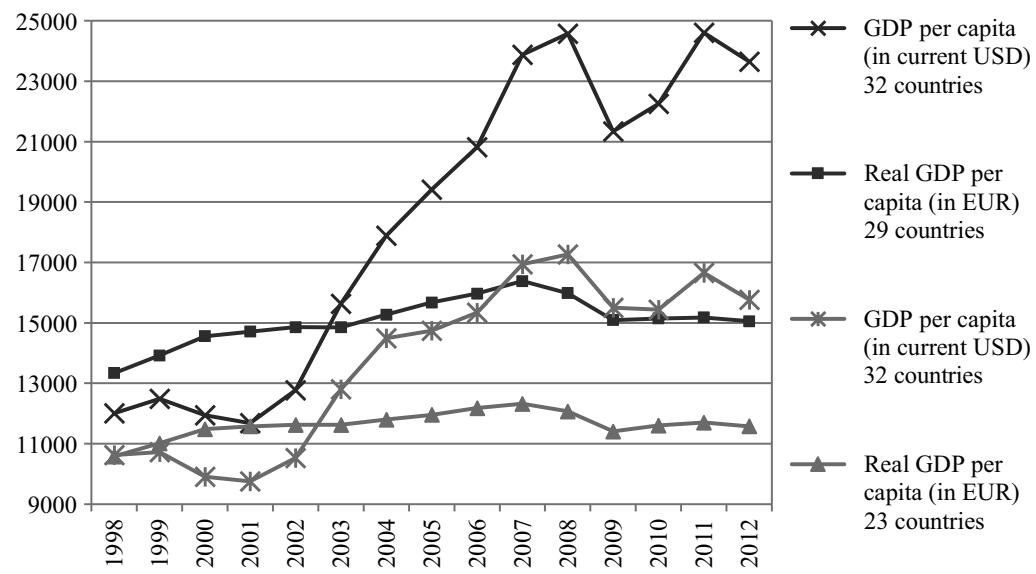

Fig. 1. Standard deviation of GDP per capita in groups of European countries

Note: for information on which countries belong to which group see Appendix Table A1. Source: Own calculations based on data from: World Development Indicators / The World Bank / UN database and Eurostat Database / Economy and finance / National accounts (including GDP) /

Auxiliary indicators to National Accounts - annual data / GDP per capita - annual Data.

and to what extent CEECs performance within each of the innovation capabilities has changed over a decade. In order to do that a number of indicators have been chosen to describe each of the innovation capabilities.

Heterogeneous and multidimensional nature of innovation capabilities makes it impossible for a single indicator to capture their complexity (Cerulli, Filippetti 2012), therefore they are usually measured by a set of indicators that are intended to represent the entire phenomenon (Cerulli 2014). Growing availability of statistical data on innovation related activities enables researchers to study processes taking place within national innovation systems in more detail as well as allows comparisons between countries (see for example Archibugi, Coco 2004; Nasir et al. 2011; Mahroumn, Al-Saleh 2013; Fagerberg et al. 2014; Khayyat, Lee 2015). Indicators chosen in this study to describe innovation capabilities of European countries are related to a relatively broad set of factors in order to capture their heterogeneous nature better: new knowledge and innovation output of the economy, participation in technology transfer in the form of inward FDI and capital goods imports, as well as absorptive capacity described by R\&D expenditures and employment, development of human resources and the use of technological infrastructure (see Table 1).

Statistical data analysis in this paper is partly based on construction of composite indexes within five types of innovation capabilities utilising indicators defined in Table 1. The data have been normalised by using the following method of data standardisation:

$$
x=\frac{\text { actual value }- \text { mean value }}{\text { standard deviation }} \text {. }
$$

This method of standardisation imposes normal distribution of the data, and allows simultaneously to eliminate the influence of extreme values as they might prove to 
Table 1. Proposed measures of innovation capabilities

\begin{tabular}{|c|c|c|c|}
\hline \multicolumn{2}{|c|}{ Innovation capability } & Indicator & Definition \\
\hline \multirow{3}{*}{\multicolumn{2}{|c|}{$\begin{array}{l}\text { (1) New knowledge } \\
\text { creation and innovation }\end{array}$}} & 1.1 & $\begin{array}{l}\text { Patent applications by residents (worldwide patent } \\
\text { applications filed through the Patent Cooperation } \\
\text { Treaty procedure or with a national patent office for } \\
\text { exclusive rights for an invention) per } 1000 \text { inhabitants }\end{array}$ \\
\hline & & 1.2 & $\begin{array}{l}\text { Scientific and technical journal articles (number } \\
\text { of scientific and engineering articles published in } \\
\text { the following fields: physics, biology, chemistry, } \\
\text { mathematics, clinical medicine, biomedical research, } \\
\text { engineering and technology, and earth and space } \\
\text { sciences) per } 1000 \text { inhabitants }\end{array}$ \\
\hline & & 1.3 & High-technology exports (\% of manufactured exports) \\
\hline \multirow{2}{*}{\multicolumn{2}{|c|}{$\begin{array}{l}\text { (2) Participation in inward } \\
\text { technology transfer/diffusion } \\
\text { processes }\end{array}$}} & 2.1 & Inward FDI stocks as \% of GDP \\
\hline & & 2.2 & $\begin{array}{l}\text { Capital goods imports (SITC } 7 \text { Machinery and } \\
\text { transport equipment) per } 1000 \text { inhabitants }\end{array}$ \\
\hline \multirow{7}{*}{$\begin{array}{l}\text { (3) } \\
\text { Absorptive } \\
\text { capacity }\end{array}$} & \multirow{2}{*}{ (a) $\mathrm{R} \& \mathrm{D}$ effort } & 3.1 & Research and development expenditure (\% of GDP) \\
\hline & & 3.2 & Researchers in R\&D (per million people) \\
\hline & \multirow{3}{*}{$\begin{array}{l}\text { (b) Quality of } \\
\text { human resources }\end{array}$} & 3.3 & $\begin{array}{l}\text { Graduates from tertiary education (ISCED 1997) in } \\
\text { the fields of science, mathematics and computing, } \\
\text { engineering, manufacturing and construction (\% of } \\
\text { total population aged } 20-29)\end{array}$ \\
\hline & & 3.4 & $\begin{array}{l}\text { Lifelong learning - participation of adults aged } 25-64 \\
\text { in education and training (in \% of total population } \\
\text { aged from } 25 \text { to } 64 \text { years) }\end{array}$ \\
\hline & & 3.5 & $\begin{array}{l}\text { Persons with tertiary education attainment aged } 25-64 \\
\text { (in \% of total population aged from } 25 \text { to } 64 \text { years) }\end{array}$ \\
\hline & \multirow{2}{*}{$\begin{array}{l}\text { (c) Technological } \\
\text { infrastructure }\end{array}$} & 3.6 & $\begin{array}{l}\text { Mobile-cellular telephone subscriptions } \\
\text { per } 100 \text { inhabitants }\end{array}$ \\
\hline & & 3.7 & Percentage of individuals using the Internet \\
\hline
\end{tabular}

Source: Author based on data from World Bank on-line database, Eurostat on-line database, UNESCO Institute for Statistics and UN on-line database.

be unreliable outliers. Equal weights have been used in calculation of the composite indexes, as there have been no a priori indications that individual indicators have been more or less important from the point of view of economic development.

The analysis covers a period of 14 years starting with 1998 and ending with 2012, but composite indexes have been calculated for two periods: base period (1998-2000) and final period (2010-2012). A three year average has been calculated for each of the indicators for both periods. To deal with data unavailability the years covered have been moved to 1999-2001 or 2000-2002 for base and 2009-2011 for final period in case of a few indicators (see Appendix Table A2 and A 3 for details on dealing with unavailable/ incomplete data). Comparative analysis between two periods has been used to determine whether Central and Eastern European countries have been able to catch up to highly developed EU countries in terms of their innovation capabilities. 


\section{Results}

As evident from the analysis of standard deviation and variation coefficients for all the indicators, the differences between European countries' performance within each of the innovation capabilities have diminished during the analysed 14-year period. The change however is more significant for a few of the indicators while in case of others the differences between country performance remain considerable (Fig. 2).

While absorptive capacity related to human resources development (with the exception of lifelong learning) and technological infrastructure have significantly lost in importance as far as differences in national performance are concerned (as evident from relatively low values of variation coefficients for indicators describing these innovation capabilities at the end of the analysed period), new knowledge and innovation development, technology transfer and absorptive capacity related to R\&D effort remain strong differentiating factors.

At the beginning of the analysed period (1998-2000) CEECs were characterised by relatively poor performance within all of the innovation capabilities and the overall predominance of the Western and Northern European countries was clearly visible. Central European countries performed slightly better than the average for the whole group of CEECs with Baltic Sea countries and Black Sea countries lagging behind (Fig. 3). Average performance of CEECs was similar to that of Southern European countries, however with considerably poorer results regarding the state of technological infrastructure. What also should be noted is consistently good performance of Baltic Sea countries regarding human resources development throughout the analysed period.

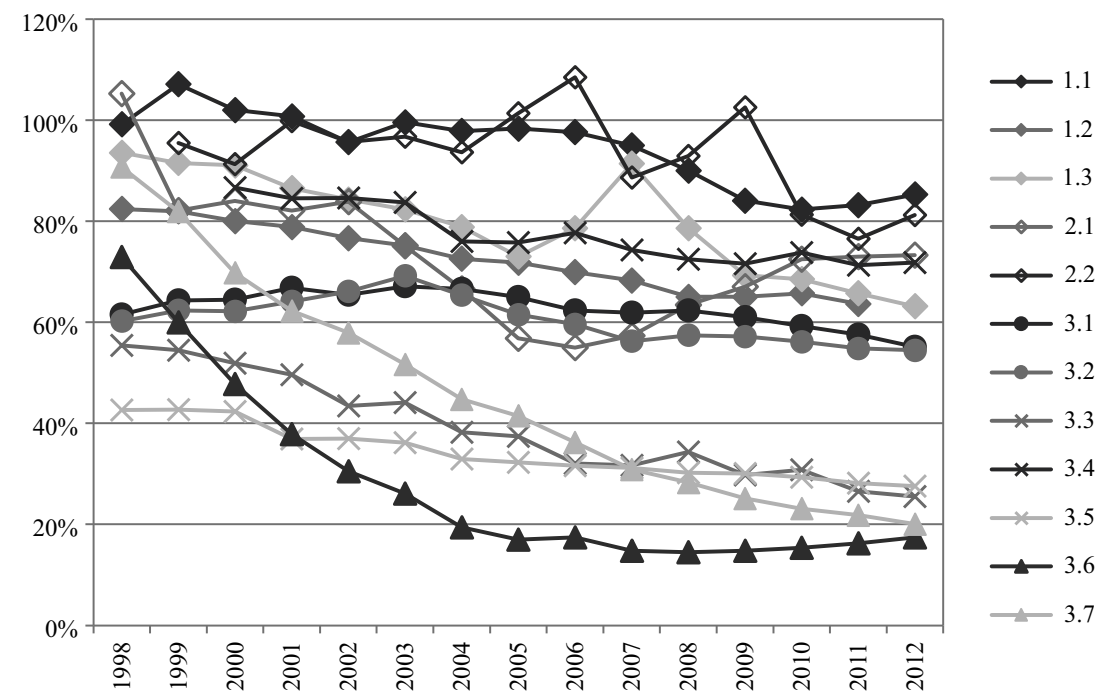

Fig. 2. Values of variation coefficients for each of the innovation capability indicators (standard deviation as \% of mean value of the indicator)

Source: Own calculations based on data from sources indicated in Table 1. 


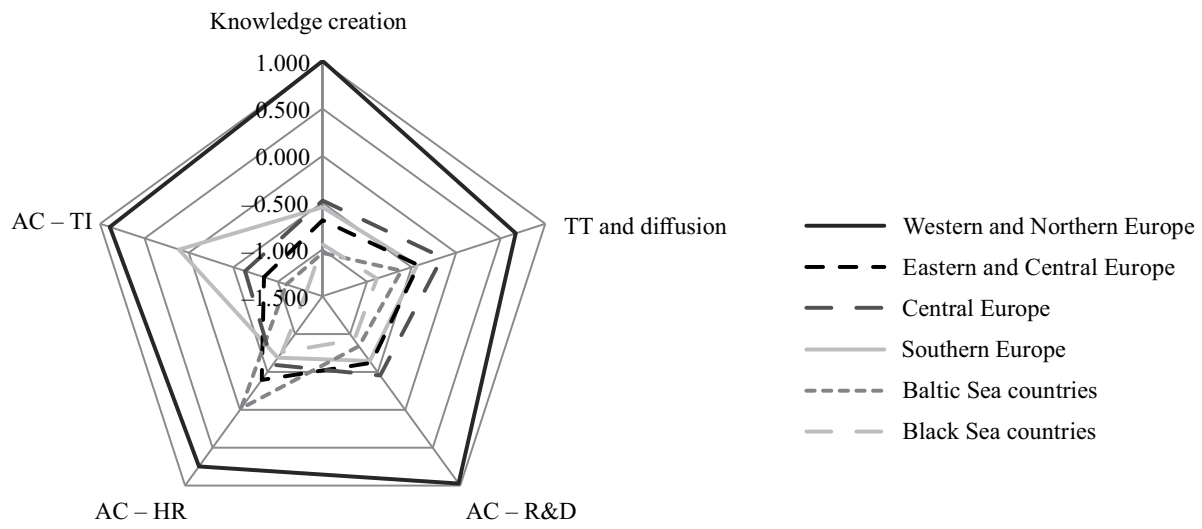

Fig. 3. 1998-2000 Innovation capabilities summary indexes values for six groups of countries

Note: AC - absorptive capacity, R\&D - research and development effort, HR - human resources, TI - technological infrastructure, TT - technology transfer.

Source: Own calculations based on data from sources indicated below Table 1.

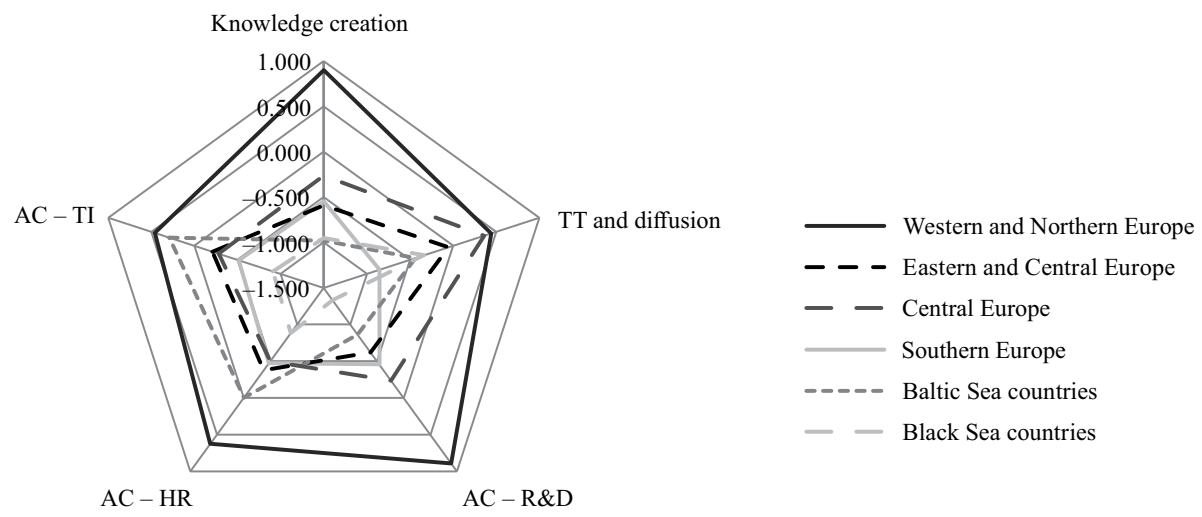

Fig. 4. 2010-2012 Innovation capabilities summary indexes values for six groups of countries Note: see Figure 3.

Source: Own calculations based on data from sources indicated below Table 1.

Figure 4 gives evidence to improvement of CEECs performance within most of the innovation capabilities in the final period of analysis (2010-2012), although a few differences even within the group are visible. Central European countries significantly improved their performance within innovation capability related to technology transfer and diffusion, while Baltic Sea countries have shown improvement of one of the aspects of their absorptive capacity - the use of technological infrastructures. Black Sea countries, on the other hand, have not shown much improvement and have been lagging behind the remaining CEECs in terms of most of the innovation capabilities.

Western and Northern European countries show the biggest advantage in terms of two innovation capabilities: new knowledge and innovation creation and absorptive capacity related to R\&D effort. The average values of composite indexes of these capabilities have not changed much since the initial 1998-2000 period either for Western and 
Northern European countries or CEECs, which means that overall there has been no or very little improvement in these areas in the latter group of countries. Again Central European countries: Czech Republic, Hungary, Slovakia and Slovenia, have performed better than the remaining countries in the group but not enough to close the gap between themselves and Western and Northern Europe.

Limited sample size (only 23 European countries for which data required to measure all innovation capabilities has been available) has not allowed to perform more sophisticated statistical analysis, which would indicate if indeed this gap is the cause of CEECs lagging behind other European countries in terms of income levels. Nevertheless, an attempt to use even the limited number of countries for regression analysis has been made. Relationships between normalised GDP per capita levels and five innovation capabilities' indexes in both periods of analysis have been considered. Results of the linear regression analysis are presented in Table 2 . Statistically significant results have been obtained only for two out of five innovation capabilities, thus failing to confirm or rule out the existence of any kind of relationship between differences in economic performance of countries and three innovation capabilities.

Table 2. Linear regression analysis between GDP per capita and five innovation capabilities' indexes

\begin{tabular}{|c|c|c|c|c|}
\hline \multicolumn{4}{|c|}{ Innovation capabilities and GDP per capita $1998-2000$} & \multirow{2}{*}{$\mathbf{R}^{2}$} \\
\hline & Coefficients & Standard error & $\mathrm{p}$ & \\
\hline Constant & 0.000 & 0.099 & 1.000 & \multirow{6}{*}{0.832} \\
\hline Knowledge creation & 1.019 & 0.362 & 0.012 & \\
\hline TT and diffusion & -0.027 & 0.178 & 0.879 & \\
\hline $\mathrm{AC}-\mathrm{R} \& \mathrm{D}$ & -0.627 & 0.352 & 0.093 & \\
\hline $\mathrm{AC}-\mathrm{HR}$ & -0.005 & 0.217 & 0.982 & \\
\hline $\mathrm{AC}-\mathrm{TI}$ & 0.668 & 0.281 & $\mathbf{0 . 0 3 0}$ & \\
\hline \multicolumn{4}{|c|}{ Innovation capabilities and GDP per capita 2010-2012 } & \multirow{2}{*}{$\mathbf{R}^{2}$} \\
\hline & Coefficients & Standard error & $\mathrm{p}$ & \\
\hline Constant & 0.000 & 0.104 & 1.000 & \multirow{6}{*}{0.816} \\
\hline Knowledge creation & 0.956 & 0.218 & 0.000 & \\
\hline TT and diffusion & -0.004 & 0.154 & 0.982 & \\
\hline $\mathrm{AC}-\mathrm{R} \& \mathrm{D}$ & 0.076 & 0.247 & 0.762 & \\
\hline $\mathrm{AC}-\mathrm{HR}$ & 0.159 & 0.214 & 0.468 & \\
\hline $\mathrm{AC}-\mathrm{TI}$ & 0.043 & 0.252 & 0.865 & \\
\hline \multicolumn{4}{|c|}{ Innovation capabilities $1998-2000$ and GDP per capita $2010-2012$} & \multirow{2}{*}{$\mathbf{R}^{2}$} \\
\hline & Coefficients & Standard error & $\mathrm{p}$ & \\
\hline Constant & 0.000 & 0.085 & 1.000 & \multirow{6}{*}{0.877} \\
\hline Knowledge creation & 0.884 & 0.309 & 0.011 & \\
\hline TT and diffusion & 0.059 & 0.152 & 0.703 & \\
\hline $\mathrm{AC}-\mathrm{R} \& \mathrm{D}$ & -0.409 & 0.300 & 0.191 & \\
\hline $\mathrm{AC}-\mathrm{HR}$ & 0.002 & 0.185 & 0.992 & \\
\hline $\mathrm{AC}-\mathrm{TI}$ & 0.566 & 0.240 & 0.031 & \\
\hline
\end{tabular}

Note: Statistically significant results have been indicated using Bold font.

Source: Own calculations based on data from sources indicated below Table 1. 
Regression results have, on the other hand, confirmed the importance of new knowledge and innovation creation capability from the point of view of differences in economic development of countries. Additionally, $\mathrm{R}^{2}$ scores indicate a high goodness of fit of the model relationships considered, which means that country differences in new knowledge and innovation creation have a good explanatory value of national variations in development levels. The analysis results also point to the significance (although lesser than in the case of new knowledge creation and innovation) of differences in development of technological infrastructure in the initial period of analysis (1998-2000) for country variations in economic development in both periods. They also confirm previous conclusions that absorptive capacity related to technological infrastructure development has ceased to be a differentiating factor in the second period of analysis (2010-2012).

\section{Conclusions}

Past research indicates that there is a positive relationship between technological/innovation capabilities and economic development. It implies that the differences in economic development may be explained by variations in country performance within certain aspects of innovation activities. However the research on CEECs performance in terms of innovation capabilities has received scant attention, with the main focus on emerging economies and/or least developed countries of the world. The work at hand fills this gap by providing evidence on the nature of innovation capabilities that differentiate CEECs and highly developed EU economies the most and indicating factors behind the continuing lagging behind of the former countries in terms of GDP per capita levels. The added value of the present work, compared to majority of previous studies on innovation capabilities of countries and of CEECs in particular, stems also from the fact that the focus has been shifted towards dynamics of CEECs' innovation systems over time. Furthermore the indicators proposed as measures of national performance within the identified innovation capabilities may be used by policy makers in CEECs to monitor progress on the path to foster their innovation capabilities, since the data have been obtained from regularly updated sources.

The analysis performed in this paper has allowed to conclude that new knowledge and innovation creation capability remains the strongest differentiating factor as well as the most important element of national innovation performance to influence variations in the level of economic development of European countries. A lingering performance gap in both new knowledge and innovation creation as well as R\&D effort can be observed between CEECs and Western and Northern European economies with evident lack of significant improvement. This indicates that attempts should be made to increase R\&D effort in CEECs, especially in the enterprise sector because of its potentially higher productivity in terms of returns in the form of new commercially applicable knowledge. New knowledge cannot be created without the advantage of high quality human resources - close attention should also be paid to quality of educational programmes and lifelong learning as a form of constant improvement of domestic human capital rather than to quantity of tertiary education graduates in CEECs, since most of them lag behind their better developed counterparts also with respect to absorptive capacity related to human resources. 
The research results have also allowed to observe positive changes in CEECs' innovation performance over time - there has been an improvement within two of the identified innovation capabilities: absorptive capacity related to the existence and use of technological infrastructure as well as participation in inward technology transfer in the form of FDI and capital goods imports. Although such improvements are important steps on the path to long term development in every economy undergoing system transformation, it is not enough to continuously feed the process of catching up to highly developed European economies.

Despite the limitations of the study arising from the relatively small country sample it has been able to show the main areas of national innovation related performance where Central and Eastern European countries are continuously falling behind their better developed European counterparts, showing little or no improvement over time. The research results indicate that CEECs indeed face the end of the era of imitation-based catching up and that continuation of the present trends in the development of their national innovation systems might result in permanent inability to reduce the gap between them and Western and Northern European countries in terms of GDP per capita levels.

\section{References}

Abramovitz, M. 1986. Catching-up, forging ahead and falling behind, Journal of Economic History 46(2): 385-406. http://dx.doi.org/10.1017/S0022050700046209

Abramovitz, M. 1994. The origins of the postwar catch-up and convergence boom, Chapter 2 in J. Fagerberg, B. Verspagen, G. N. von Tunzelmann (Eds.). The dynamics of technology, trade and growth. Aldershot: Edward Elgar.

Archibugi, D.; Coco, A. 2004. A new indicator of technological capabilities for developed and developing countries (ArCo), World Development 32(4): 629-654.

http://dx.doi.org/10.1016/j.worlddev.2003.10.008

Archibugi, D.; Coco, A. 2005. Measuring technological capabilities at the country level: a survey and a menu for choice, Research Policy 34(2): 175-194.

http://dx.doi.org/10.1016/j.respol.2004.12.002

Archibugi, D.; Denni, M.; Filippetti, A. 2009. The technological capabilities of nations: the state of the art of synthetic indicators, Technological Forecasting \& Social Change 76(7): 917-931. http://dx.doi.org/10.1016/j.techfore.2009.01.002

Benhabib, J.; Spiegel, M. 1994. The role of human capital in economic development: evidence from aggregate cross-country data, Journal of Monetary Economics 34(2): 143-173.

http://dx.doi.org/10.1016/0304-3932(94)90047-7

Castellacci, F. 2003. A neo-schumpeterian approach to why growth rates differ, Working paper 04/03. University of Oslo, Strategic University Programme - Globalisation as a Transformative Force.

Castellacci, F.; Natera, J. M. 2013. The dynamics of national innovation systems: a panel cointegration analysis of the coevolution between innovative capability and absorptive capacity, $R e$ search Policy 42(3): 579-594. http://dx.doi.org/10.1016/j.respol.2012.10.006

Cerulli, G. 2014. The impact of technological capabilities on invention: an investigation based on country responsiveness scores, World Development 59(3): 147-165.

http://dx.doi.org/10.1016/j.worlddev.2014.01.019 
Cerulli, G.; Filippetti, A. 2012. The complementary nature of technological capabilities: measurement and robustness issues, Technological Forecasting \& Social Change 79(5): 875-887.

http://dx.doi.org/10.1016/j.techfore.2011.12.002

Cohen, W. M.; Levinthal, D. A. 1990. Absorptive capacity: a new perspective on learning and innovation, Administrative Science Quarterly 35(1): 128-152. http://dx.doi.org/10.2307/2393553

Dosi, G.; Pavitt, K.; Soete, L. 1990. The economics of technical change and international trade. London: Harvester Whetsheaf.

Faber, J.; Hesen, A. B. 2004. Innovation capabilities of European nations cross-national analyses of patents and sales of product innovations, Research Policy 33(2): 193-207.

http://dx.doi.org/10.1016/S0048-7333(03)00122-7

Fagerberg, J. 1987. A technology gap approach to why growth rates differ, Research Policy 16(2): 87-99. http://dx.doi.org/10.1016/0048-7333(87)90025-4

Fagerberg, J. 1988a. International competitiveness, Economic Journal 98(391): 355-374.

http://dx.doi.org/10.2307/2233372

Fagerberg, J. 1988b. Why growth rates differ, Chapter 20 in G. Dosi, C. Freeman, R. R. Nelson, G. Silverberg, L. Soete (Eds.). Technical change and economic theory. London: Pinter.

Fagerberg, J. 1994. Technology and international differences in growth rates, Journal of Economic Literature 32(3): 1147-1175.

Fagerberg, J. 2000. Technological progress, structural change and productivity growth: a comparative study, Structural Change and Economic Dynamics 11(4): 393-411.

http://dx.doi.org/10.1016/S0954-349X(00)00025-4

Fagerberg, J.; Feldman, M. P.; Srholec, M. 2014. Technological dynamics and social capability: US states and European nations, Journal of Economic Geography 14(2): 313-337.

http://dx.doi.org/10.1093/jeg/lbt026

Fagerberg, J.; Godinho, M. M. 2005. Innovation and catching-up, Chapter 19 in J. Fagerberg, D. C. Mowery, R. R. Nelson (Eds.). The Oxford handbook of innovation. Oxford: Oxford University Press.

Fagerberg, J.; Srholec, M.; Knell, M. 2007. The competitiveness of nations: why some countries prosper while others fall behind, World Development 35(10): 1595-1620.

http://dx.doi.org/10.1016/j.worlddev.2007.01.004

Fagerberg, J.; Srholec M. 2008. National innovation systems, capabilities and economic development, Research Policy 37(9): 1417-1435. http://dx.doi.org/10.1016/j.respol.2008.06.003

Fagerberg, J.; Srholec, M. 2013. Knowledge, capabilities and the poverty trap: the complex interplay between technological, social and geographical factors, Chapter 7 in P. Meusburger, J. Glückler, M. el Meskioui (Eds.). Knowledge and the economy. Dordrecht: Springer.

http://dx.doi.org/10.1007/978-94-007-6131-5_7

Fagerberg, J.; Verspagen, B. 2002. Technology-gaps, innovation-diffusion and transformation: an evolutionary interpretation, Research Policy 31(8-9): 1291-1304.

http://dx.doi.org/10.1016/S0048-7333(02)00064-1

Fagerberg, J.; Verspagen, B. 2003. Innovation, growth and economic development: why some countries succeed and others don't, in First GLOBELICS Conference: Innovation Systems and Development Strategies for the Third Millennium, 2-6 November 2003, Rio, Brazil.

Fagerberg, J.; Verspagen, B. 1996. Heading for divergence? Regional growth in Europe reconsidered, Journal of Common Market Studies 34(3): 431-448.

http://dx.doi.org/10.1111/j.1468-5965.1996.tb00580.x

Filippetti, A.; Peyrache, A. 2011. The patterns of technological capabilities of countries: a dual approach using composite indicators and data envelopment analysis, World Development 39(7): 1108-1121. http://dx.doi.org/10.1016/j.worlddev.2010.12.009 
Freeman, C.; Clark, J.; Soete, L. 1982. Un-employment and technical innovation: a study of long waves and economic development. London: Frances Printer.

Freeman, C. 2002. Continental, national and sub-national innovation systems - complementarity and economic growth, Research Policy 31(2): 191-211.

http://dx.doi.org/10.1016/S0048-7333(01)00136-6

Furman, J. L.; Hayes, R. 2004. Catching up or standing still? National innovative productivity among "follower" countries, 1978-1999, Research Policy 33(9): 1329-1354.

http://dx.doi.org/10.1016/j.respol.2004.09.006

Furman, J. L.; Porter, M. E.; Stern, S. 2002. The determinants of national innovative capacity, Research Policy 31(6): 899-933. http://dx.doi.org/10.1016/S0048-7333(01)00152-4

Goo, Y.; Park, H. 2007, Economic growth and convergence with international differences in technology, Journal of Macroeconomics 29(1): 145-168.

http://dx.doi.org/10.1016/j.jmacro.2005.04.007

Hasan, I.; Tucci, C. L. 2010. The innovation-economic growth nexus: global evidence, Research Policy 39(10): 1264-1276. http://dx.doi.org/10.1016/j.respol.2010.07.005

Khayyat, N. T.; Lee, J.-D. 2015. A measure of technological capabilities for developing countries, Technological Forecasting \& Social Change 92(1): 210-223.

http://dx.doi.org/10.1016/j.techfore.2014.09.003

Keller, W. 1996. Absorptive capacity: on the creation and acquisition of technology in development, Journal of Development Economics 49(1): 199-227.

http://dx.doi.org/10.1016/0304-3878(95)00060-7

Kim, L. 1997. Imitation to innovation: the dynamics of korea's technological learning. Harvard: Harvard Business School Press.

Kravtsova, V.; Radosevic, S. 2012. Are systems of innovation in Eastern Europe efficient?, Economic Systems 36(1): 109-126. http://dx.doi.org/10.1016/j.ecosys.2011.04.005

Lall, S. 1992. Technological capabilities and industrialization, World Development 20(2): 165-186.

Mahroumn, S.; Al-Saleh, Y. 2013. Towards a functional framework for measuring national innovation efficacy, Technovation 33(10-11): 320-332.

http://dx.doi.org/10.1016/j.technovation.2013.03.013

Nasir, A.; Ali, T. M.; Shahdin, S.; Rahman T. U. 2011. Technology achievement index 2009: ranking and comparative study of nations, Scientometrics 87(1): 41-62.

http://dx.doi.org/10.1007/s11192-010-0285-6

Papageorgiou, C. 2002. Technology adoption, human capital and growth theory, Review of Development Economics 6(3): 351-368. http://dx.doi.org/10.1111/1467-9361.00160

Stokke, H. 2008. Productivity growth and organizational learning, Review of Development Economics 12(4): 764-778. http://dx.doi.org/10.1111/j.1467-9361.2008.00445.x

Verspagen, B. 1991. A new empirical approach to catching up or falling behind, Structural Change and Economic Dynamics 2(2): 359-380. http://dx.doi.org/10.1016/S0954-349X(05)80008-6 


\section{APPENDIX}

Table A1. Countries in sample groups used for comparisons in the study

\begin{tabular}{c|l}
\hline No. of countries & \multicolumn{1}{c}{ Country names and groups } \\
\hline & Western and Northern Europe: \\
& Austria, Denmark, Finland, France, Germany, Ireland, Netherlands, \\
& Sweden, United Kingdom \\
& Southern Europe: \\
& Greece, Italy, Portugal, Spain \\
& Central and Eastern Europe: \\
& Estonia, Latvia, Lithuania, Poland (Baltic Sea countries), \\
& Czech Republic, Hungary, Slovakia, Slovenia (Central Europe), Bulgaria, \\
& Romania (Black Sea countries) \\
\hline 29 countries & the above + Belgium, Croatia, Cyprus, Iceland, Luxembourg, Norway \\
\hline 32 countries & the above + Malta, Serbia, Turkey \\
\hline
\end{tabular}

Source: Author.

Table A2. Base and final period years for indicators of innovation capabilities

\begin{tabular}{ccc}
\hline Indicator No. & Base period 1998-2000 & Final period 2010-2012 \\
\hline 1.2 & no change & 2009-2011 \\
\hline 2.2 & $1999-2001$ & no change \\
\hline 3.3 & $1999-2001$ & no change \\
\hline 3.4 & $2001-2003$ & no change \\
\hline 3.5 & $1999-2001$ & no change
\end{tabular}

Source: Author.

Table A3. Number and percentage of incomplete data* for indicators and countries

\begin{tabular}{lcccccccccccc}
\hline & \multicolumn{10}{c}{$1998-2000$} \\
\hline Indicator No. & 1.1 & 1.2 & 1.3 & 2.1 & 2.2 & 3.1 & 3.2 & 3.3 & 3.4 & 3.5 & 3.6 & 3.7 \\
\hline $\begin{array}{l}\text { incomplete data } \\
\text { for No. of countries }\end{array}$ & & & & 2 & & 3 & 4 & 2 & 5 & 2 & & \\
\hline $\begin{array}{l}\text { incomplete data } \\
\text { for countries (\%) }\end{array}$ & 0.0 & 0.0 & 0.0 & 8.7 & 0.0 & 13.0 & 17.4 & 8.7 & 21.7 & 8.7 & 0.0 & 0.0 \\
\hline & & & & & & $2010-2012$ & & & & \\
\hline Indicator No. & 1.1 & 1.2 & 1.3 & 2.1 & 2.2 & 3.1 & 3.2 & 3.3 & 3.4 & 3.5 & 3.6 & 3.7 \\
\hline $\begin{array}{l}\text { incomplete data } \\
\text { for No. of countries }\end{array}$ & 2 & & & & & 1 & 2 & 1 & & & & \\
\hline $\begin{array}{l}\text { incomplete data } \\
\text { for countries (\%) }\end{array}$ & 8.7 & 0.0 & 0.0 & 0.0 & 0.0 & 4.3 & 8.7 & 4.3 & 0.0 & 0.0 & 0.0 & 0.0 \\
\hline
\end{tabular}

Note: *two year average or data for only one year used instead of a three year average due to lack of data. Source: Author.

Monika KONDRATIUK-NIERODZIŃSKA. Assoc. Prof. Dr of Economic Sciences. Lecturer at University of Bialystok, Faculty of Economics and Management, Department of Economic Systems. Research interests cover areas of regional and national innovation systems characteristics, innovation system functions and elements, as well as measurement and comparisons of regional and national innovation performance. 